\title{
PENGARUH FAKTOR SOSIAL EKONOMI TERHADAP LOYALITAS KONSUMEN DI PASAR TRADISIONAL AMPEL KABUPATEN BOYOLALI
}

\author{
Eka Dwi Fitriani, Bayu Nuswantara \\ Program Studi Agribisnis, Fakultas Pertanian dan Bisnis, Universitas Kristen Satya Wacana \\ Jl. Diponegoro 52-60 Salatiga - Indonesia 50711 Telp : (0298) 321212 \\ E-mail : 522013002@student.uksw.edu
}

\begin{abstract}
This study examines socioeconomic factors on consumer loyalty in choosing to shop at the traditional Ampel market in Boyolali Regency. In order for traditional markets to survive and develop in the competitive business world in competing for consumers, it must be able to understand it's consumers. Many factors can influence consumer loyalty in choosing to shop in traditional markets. In this study the factors that are thought to influence are product prices, product quality, merchant service, product location and market days. The type of research used is a survey with 50 sampling using incidental sampling. The type of data used is primary data and secondary data. Data collection techniques using questionnaires and data analysis techniques used multiple linear regression. Instrument test results show all valid and reliable. Multiple linear regression test shows $Y=-9,199+0.510 X 1+0.460 X 2-$ $0.192 X 3+0.708 X 4+0.551 X 5$. It is shows that product price variables, product quality, market location and market day have a positive effect on consumer loyalty.
\end{abstract}

Keywords : Price, Quality, Service, Location, Market Day, Consumer Loyalty

\begin{abstract}
Abstrak: Penelitian ini menguji pengaruh faktor sosial ekonomi terhadap loyalitas konsumen dalam memilih berbelanja di pasar tradisional Ampel Kabupaten Boyolali. Agar pasar tradisional tetap bertahan dan berkembang dalam dunia bisnis yang penuh persaingan dalam memperebutkan konsumen, maka harus mampu memahami konsumennya. Banyak faktor yang dapat mempengaruhi loyalitas konsumen dalam memilih berbelanja di pasar tradisional. Pada penelitian ini faktor yang diduga mempengaruhi adalah harga produk, kualitas produk, pelayanan pedagang, lokasi produk dan hari pasaran. Jenis penelitian yang digunakan adalah survey dengan pengambilan sampel sebanyak 50 menggunakan incidental sampling. Jenis data yang digunakan adalah data primer dan data sekunder. Teknik pengumpulan data menggunakan kuisioner dan teknik analisis data yang digunakan regresi linier berganda. Hasil uji instrumen menunjukkan semua valid dan reliabel. Uji regresi linier berganda menunjukkan $Y=-9,199+0,510 X_{1}+0,460 X_{2}-0,192 X_{3}+0,708 X_{4}+$ $0,551 \mathrm{X}_{5}$. Menunjukkan bahwa variabel harga produk, kualitas produk, lokasi pasar dan hari pasaran berpengaruh positif terhadap loyalitas konsumen.
\end{abstract}

Kata kunci: Harga, Kualitas, Pelayanan, Lokasi, Hari Pasaran dan Loyalitas Konsumen

\section{PENDAHULUAN}

Pada hampir semua kota besar di Indonesia, secara berangsur-angsur pasar tradisional mengalami penyusutan sehingga berpengaruh terhadap kegiatan ekonomi lokal baik pendapatan pedagang maupun penerimaan pemerintah daerah. Penyusutan terjadi karena berubahnya preferensi masyarakat berbelanja dari pasar tradisional ke pasar semimodern dan modern. Pasar tradisional identik dengan kondisi lingkungan yang kotor, kumuh, becek dan bau berbeda halnya dengan pasar modern yang menawarkan fasilitas lebih menarik dan 
dengan suasana yang lebih nyaman. Kenyamanan berbelanja biasanya menjadi alasan bagi konsumen untuk lebih memilih pasar modern dibandingkan dengan pasar tradisional (Mukhlas, 2007).

Agar pasar tradisional bisa tetap bertahan dan berkembang dalam dunia bisnis yang penuh persaingan dalam memperebutkan konsumen, maka harus mampu memahami konsumenya secara menyeluruh, karena konsumen merupakan pasar sasaran suatu produk. Diterima atau tidaknya produk tergantung persepsi konsumen atas produk tersebut. Jika konsumen merasa produk tersebut dapat memenuhi kebutuhan dan keinginannya pasti produk tersebut akan dibeli konsumen.

Namun demikian beberapa faktor yang dapat mempengaruhi orang membeli pada pasar tradisoinal, bahkan mereka memiliki loyalitas yang sangat tinggi. Loyalitas adalah sikap menyenangi terhadap suatu merek yang dipresentasikan dalam pembelian yang konsisten terhadap merek itu sepanjang waktu (Sutisna, 2003). Jadi di sini konsumen mempunyai loyalitas terhadap keberadaan pasar tradisional.

Menurut Kotler dan Armstrong (2002) keputusan pembelian merupakan tahap proses keputusan dimana konsumen secara actual melakukan pembelian suatu produk.Terdapat beberapa faktor yang dapat mempengaruhi keputusan konsumen untuk melakukan pembelian bahkan mempunyai loyalitas dapat diukur dengan variabel harga produk, pelayanan pedagang, kualitas produk, kondisi pasar, lokasi pasar, keragaman produk.

Harga adalah jumlah uang (kemungkinan ditambah beberapa barang) yang dibutuhkan untuk memperoleh beberapa kombinasi sebuah produk dan pelayanan yang menyertainya (Angipora,2002). Purnama (2006) mengatakan kualitas adalah keseluruhan ciri-ciri dan karakteristik dari suatu produk atau layanan menyangkut kemampuan untuk memenuhi kebutuhan-kebutuhan yang telah ditentukan atau yang bersifat paten.

Pelayanan atau jasa adalah setiap tindakan atau perbuatan yang dapat ditawarkan oleh suatu pihak kepada pihak lain, yang pada dasarnya bersifat intangible (tidak berwujud fisik) dan tidak menghasilkan kepemilikan sesuatu (Tjiptono, 2002). Lokasi sangat mempengaruhi keinginan seorang konsumen untuk melakukan pembelian. Pada umumnya, konsumen akan memilih toko yang dekat dengan tempat tinggal mereka (Loundon dan Bitta dalam Susanta, 1999).

Walupun pasar tradisioanal saat ini mulai ditinggalkan tidak serta merta menghapus keberadaan pasar tradisional, masih ada cukup banyak pasar tradisional di Indonesia. Pasar Ampel Boyolali mempunyai banyak peasaing dari sesama pasar tradisional, tetapi pasar ampel tergolong pasar yang lumayan besar, daerah yang luas serta banyaknya pengunjung. Meskipun memiliki banyak pengunjung yang loyal, tetapi banyak munculnya pasar-pasar modern di boyolali dapat berakibat pada pelanggan yang kemungkinan akan berpindah tempat berbelanja. Pengaruh faktor sosial ekonomi terhadap loyalitas konsumen pada Pasar Tradisional Ampel Kabupaten Boyolali, seperti harga produk, kualitas produk, keragaman produk, pelayanan pedagang, lokasi pasar, kondisi pasar dan hari pasaran.

Dari latar belakang diatas dapat dirumuskan permasalahan menyangkut hal-hal yang terkait dengan pasar tradisional yaitu: bagaimanakah gambaran pasar tradisional dilihat dari sisi loyalitas konsumen yang berbelanja di pasar tersebut, serta bagaimanakah pengaruh faktor sosial ekonomi yang meliputi: harga produk, pelayanan pedagang, kualitas produk, lokasi pasar dan hari pasaran terhadap loyalitas konsumen di pasar tradisional untuk itu akan dilakukan penelitian di Pasar Tradisional Ampel Kabupaten Boyolali.

Berdasarkan latar belakang dan permasalahan di atas, maka dapat dirumuskan tujuan penelitian sebagai berikut (1) Mendiskripsikan loyalitas konsumen di Pasar Tradisional Ampel Kabupaten Boyolali (2) Mengalisis pengaruh faktor sosial ekonomi yang meliputi: harga produk, kualitas produk, , pelayanan pedagang, lokasi pasar dan hari pasaran terhadap loyalitas konsumen di Pasar Tradisional Ampel Kabupaten Boyolali.

\section{METODE PENELITIAN}

Obyek dari penelitian ini adalah pasar tradisional yang berada di Kabupaten Boyolali yaitu di Pasar Tradisional Ampel (Kecamatan Ampel). Kegiatan penelitian dilaksanakan pada 
bulan April sampai bulan Mei 2018 selama kurang lebih 30 hari, adapun yang menjadi subyek dari penelitian ini adalah konsumen pada pasar tradisional tersebut. Data yang dibutuhkan dalam penelitian adalah data primer berupa jawaban responden. Metoda pengumpulan data dilakukan dengan menggunakan survei melalui kuesioner yang diberikan langsung kepada responden. Sampel penelitian secara incidental sampling, teknik Incidental Sampling adalah teknik penentuan sampel berdasarkan kebetulan, yaitu siapa saja yang secara kebetulan/insidental bertemu dengan peneliti dapat digunakan sebagai sampel, bila dipandang orang yang kebetulan ditemui itu cocok dengan sumber data. (Sugiono, 2012). Pengambilan sampel dilakukan pada konsumen di Pasar Tradisional Ampel Kabupaten Boyolali sebanyak 50 orang.

\section{Uji Validitas}

Uji validitas digunakan untuk mengukur sah atau valid tidaknya suatu kuesioner. Suatu kuesioner dikatan valid jika pertanyaan pada kuesioner mampu mengungkapkan sesuatu yang akan diukur oleh kuesioner tersebut. Uji signifikansi dilakukan dengan membandingkan nilai $r$ hitung dengan $r$ tabel untuk degree of freedom $(\mathrm{df})=\mathrm{n}-2$, dalam hal ini $\mathrm{n}$ adalah junmalh sampel dan alpha $=0,05$. Jika $r$ hitung lebih besar dari table dan nilai positif, maka butir atau pertanyaan atau indicator tersebut diyatakan valid (Ghozali, 2012).

\section{Uji Reliabilitas}

Uji reliabilitas adalah alat untuk mengukur sumber kuesioner yang merupakan indicator dari variabel atau konstuk. Suatu kuesioner dikatakan reliable atau handal jika jawaban seseorng terhadpa pernyataan adalah konsisten atau stabil dari waktu ke waktu (Ghozali, 2012). Kuesioner dapat dikatakan reliabel jika mempunyai koefisien kordinasi lebih dari 0,6. Hasil yang diperoleh dari uji reliabilitas terhadap kuesioner pada masing-masing variabel adalah sebagai berikut :

\begin{tabular}{lccc}
\hline \multicolumn{1}{c}{ Variabel } & $\begin{array}{c}\text { Koefisien } \\
\text { Alpha }\end{array}$ & $\begin{array}{c}\text { Critical } \\
\text { Value }\end{array}$ & Keterangan \\
\hline $\begin{array}{l}\text { Semua } \\
\text { variabel X } \\
\text { dan Y }\end{array}$ & 0,930 & $>0,6$ & Reliabel \\
\hline Sumber : Data diolah 2018 & & \\
\hline
\end{tabular}

Sumber : Data diolah 2018

\section{Alat Analisis dan Uji Hipotesis}

Hipotesis dala penelitian ini akan diuji dengan menggunakan analisis regresi linier berganda. Sebelum dilakukan pengujian hipotesis penelitian, maka akan dilakukan uji asumsi klasik terlebih dahulu. Adapun pengujian asumsi klasik yang dipergunakan adalah uji normalitas, uji multikolineritas, uji heterokadasitas.

\section{HASIL DAN PEMBAHASAN}

\section{Karakteristik Responden}

Dari kuisioner yang disebar sebanyak 50 responden, didapatkan data tentang karakteristik responden yaitu berdasarkan usia, responden paling banyak berusia antara 40-49 tahun yaitu sebanyak $32 \%$. Berdasarkan jenis kelamin perempuan yaitu sebanyak $80 \%$, sedangkan laki-laki yaitu sebanyak $20 \%$. Berdasarkan pendidikan, reponden paling banyak setingkat SMA/SMK sebanyak $34 \%$. Berdasarkan pekerjaan, reponden paling banyak pekerja wiraswasta yaitu sebnyak $34 \%$. Berdasarkan frekuensi berkunjung yaitu sebanyak 2-3 kali sebesar 70\%. Berdasarkan pendapatan, responden paling banyak pendapatannya $<\mathrm{Rp} 1.500 .000$ sebesar $44 \%$.

\section{Uji Asumsi Klasik \\ Uji Normalitas}

Uji Normalitas bertujuan untuk menguji apakah dalam model regresi, variabel pengganggu atau residual memiliki distribusi normal. Dalam penelitian ini metode yang digunakan yaitu dengan melihat probability plot yang membangdingkan distributif komulatif dari distribusi normal. Distribusi normal akan menetukan garis lurus diagonal, dan ploting data residual akan dibandingkan dengan garis diagonal. Jika distribusi data residual normal, maka garis yang menggambarkan data sesunggguhnya akan mengikuti garis diagonalnya (Ghozali, 2012). 


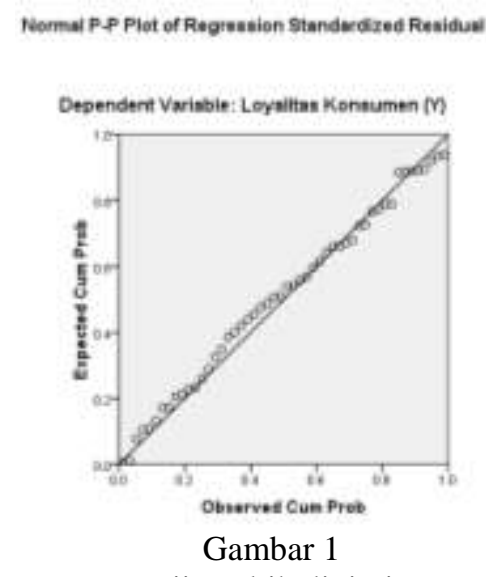

Uji Multikolinieritas

Dapat dilihat pada Gambar 1 diatas, titiktitik berada diantara garis diagonal dikatakan normal.

\section{Uji Multikolineritas}

Untuk mendeteksi ada tidaknya multikolinieritas di dalam regresi, maka dapat dilihat dari nilai tolerance dan variance inflation factor (VIF). Nilai tolerance yang terendah sama dengan nilai VIF tinggi (karena $\mathrm{VIF}=1 /$ Tolerance $)$. Nilai cut off yang umum dipakai untuk menunjukkan tingkat multikolinieritas adalah nilai tolerance $\leq 0,10$ atau sama dengan nilai $\geq 10$ (Ghozali, 2012)

Dari uji multikolinieritas yang dilakukan didapatkan hasil bahwa seluruh variabel penjelas memiliki nilai VIF kurang dari 10 ( Variabel harga produk $(\mathrm{X} 1)=1,871$, kualitas produk $(\mathrm{X} 2)=2,511$, keragaman produk $(\mathrm{X} 3)$ $=1,706$, pelayanan pedagang $(\mathrm{X} 4)=1,736$, Lokasi pasar $(\mathrm{X} 5)=5,362$, kondisi pasar $(\mathrm{X} 6)$
$=6,683$, hari pasaran $(X 7)=1,361)$ sehingga dapat disimpulkan bahwa model regresi tidak memiliki masalah multikolinieritas.

\section{Uji Heterokedasitas}

Cara mendeteksi ada tidaknya heterokedastisitas yaitu dengan melihat grafik plot antara nilai prediksi veriabel terikat (dependen) yaitu ZPRED dengan residualnya SRESID. Deteksi ada tidaknya heterokedastisitas dapat dilakukan dengan melihat pola tertentu pada grafik scatterplot antara SRESID dan ZPRED dimana sumbu Y adalah $\mathrm{Y}$ yang telah diprediksi, dan sumbu $\mathrm{X}$ adalah residual (Y prediksi - Y sesungguhnya) yang telah di Studentized (Ghozali, 2012).

senteisiot

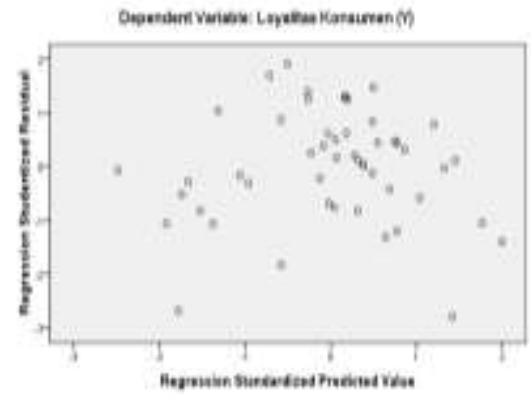

Gambar 2

Uji Heterokedastisitas

Dapat dilihat pada Gambar 2 diatas, titiktitik menyebar merata dapat disimpulkan bahwa tidak mengalami masalah heterokedasitas.

Tabel 1. Hasil Regresi Linear Berganda

\begin{tabular}{|c|l|c|c|c|c|}
\hline No & \multicolumn{1}{|c|}{ Variabel } & $\begin{array}{c}\text { Koefisien } \\
\text { Regresi (B) }\end{array}$ & t-hitung & Prob. Sig & Keterangan \\
\hline 1 & Konstanta & $-9,199$ & -1.803 & 0,078 & Signifikan \\
2 & Harga produk (X1) & 0,510 & 2,498 & 0,016 & Signifikan \\
3 & Kualitas produk (X2) & 0,460 & 2,237 & 0,030 & Signifikan \\
4 & Pelayanan pedagang (X3) & $-0,192$ & $-1,078$ & 0,287 & Tidak Signifikan \\
5 & Lokasi pasar (X4) & 0,708 & 2,495 & 0,016 & Signifikan \\
6 & Hari pasaran (X5) & 0,551 & 2,423 & 0,020 & Signifikan \\
\hline & R $^{2}$ & 0,615 & & \\
& Adj R & 0,571 & & \\
& F-hitung & 14,047 & & \\
& Prob. F & 0,000 & & \\
\end{tabular}

Sumber: Data diolah 2018 
Hasil regresi berganda tersebut dapat dilihat dari Tabel 1.

Dapat dilihat bahwa variabel harga produk, kualitas produk, lokasi pasar, dan hari pasaran berpengaruh secara signifikan terhadap loyalitas konsumen sebagai tempat berbelanja, dengan demikian hipotesis 1, hipotesis 2, hipotesis 4 , dan hipotesis 5 mendapat dukungan empiris dalam penelitian ini. Tabel 1 juga memperlihatkan bahwa variabel pelayanan tidak mempunyai pengaruh terhadap loyalitas konsumen dalam memilih pasar tradisional sebagai tempat berbelanja, dengan demikian dan hipotesis 3 tidak mendapat dukunagn empiris dalam penelitian ini.

Menggunakan taraf signifikansi $(\alpha)=0,05$ Hasil uji F menunjukkan nilai F sebesar 14,047 dan signifikan pada $\alpha=5 \%$. Artinya variabel harga produk, kualitas produk, keragamn produk, pelayanan pedagang, lokasi pasar, dan hari pasaran mempunyai pengaruh yang signifikan secara bersama-sama terhadap loyalitas konsumen dalam memilih pasar tradisional sebagai tempat berbelanja.

Tabel 1 juga memperlihatkan bahwa besarnya koefisien determinasi ( $\mathrm{R}$ square) adalah 0,615. Hal ini menunjukkan bahwa sekitar $61,5 \%$ loyalitas konsumen dalam memilih pasar tradisional sebagai tempat berbelanja dapat dijelaskan oleh variabel harga produk, kualitas produk, pelayanan pedagang, lokasi pasar, kondisi pasar dan hari pasaran sedangkan sisanya $38,5 \%$ dipengarui variabel lain.

Hipotesis 1 menyatakan bahwa harga produk mempunyai pengaruh yang signifikan terhadap loyalitas konsumen dalam memilih pasar tradisional ampel sebagai tempat berbelanja dapat diterima. Dapat disimpulkan bahwa penetapan harga produk yang kompetitif, harga yang sesuai, dan adanya potongan harga akan meningkatkan loyalitas konsumen untuk memilih pasar tradisioanl Ampel Boyolali sebagai tempat berelanja. Hasil pengujian ini relevan dengan penelitian yang dilakukan oleh Mayasari (2009) yang menyatakan bahwa harga berpengaruh signifikan (positif) terhadap loyalitas konsumen di pasar tradisional.

Sementara itu hipotesis 2 yang menyatakan bahwa kualitas produk mempunyai pengaruh yang signifikan terhadap loyalitas konsumen dalam memilih berbelanja di pasar tradisional dapat di terima. Dapat disimpulkan bahwa peningkatan kualitas produk seperti kualitas mampu bersaing dengan pasar lain, sesuai dengan harga yang ditawarkan, kualitas beraneka ragam, memenuhi criteria jual, dan kualitas produk baik, segar dan aman di konsumsi akan meningkatkan loyalitas konsumen untuk memilih pasar tradisional ampel boyolali sebagai tempat berbelanja. Hasil penelitian ini relevan dengan penelitian dari Mayasari (2009) yang menyatakan bahwa kualitas produk berpengaruh signifikan (positif) terhadap loyalitas konsumen dalam berbelanja.

Pada hipotesis 3 yang menyatakan bahwa pelayanan pedagang tidak berpengaruh signifikan terhadap loyalitas konsumen dalm memilih pasar tradisional sebagai tempat berbelanja tidak dapat diterima (ditolak). Dapat disimpulkan bahwa peningkatan pelayanan pedagang seperti cepat dalam melayani pembeli, sikap yang ramah, kepuasan konsumen, terdapat tempat kritik dan saran, dan tidak membeda-bedakan pelanggan. Tidak meningkatkan loyalitas konsumen untuk memilih pasar tradisional ampel boyolali sebagai tempat berbelanj. Hasil penelitain ini berbeda dengan oenelitian yang dilakukan oleh Mayasari (2009) yang menyatakan bahwa pelayanan berpengauh signifikan (positif) terhadap loyalitas konsumen.

Hipotesis 4 yang menyatakan bahwa lokasi pasar berpengaruh signifikan terhadap loyalitas konsumen dalam memilih pasar tradisional sebagai tempat berbelanja dapat diterima. Dengan demikian dapat disimpulkan bahwa peningkatan lokasi pasar seperti berdasarkan, mudah transportasi, waktu tempuh, jarak dari rumah, lokasi strategi, dekat pusat keramaian dapat meningkatan loyalitas konsumen untuk memilih pasar tradisional ampel boyolali sebagai tempat berbelanja. Hasil penelitian ini relevan dengan yang dikemukan oleh Mayasari (2009) dan Asri (2010) yang menyatakan bahwa lokasi pasar berpengaruh terhadap loyalitas konsumen dalam memilih berbelanja.

Pada hipotesis 5 yang menyatakan bahwa hari pasaran berpengaruh signifikan terhadap loyalitas konsumen dalam memilih berbelanja di pasar tradisional dapat diterima. Dapat disimpulkan bahwa peningkatan hari pasaran seperti lebih banyak pedagang, pilihan produk lebih banyak, lebih menarik, lebih ramai, dan 
hanya belanja di hari pasaran akan meningkatkan loyalitas konsumen untuk memilih pasar tradisional ampel boyolali sebagai tempat berbelanja. Hasil penelitian relevan karena tidak ada dalam penelitian terdahulu yang membahas tentang hari pasaran di pasar tradisional.

\section{KESIMPULAN}

Berdasarkan hasil analisis yang telah dilakukan maka dapat disimpulkan bahwa variabel harga produk, kualitas produk, lokasi produk dan hari pasaran berpengaruh positif dan signifikan terhadap loyalitas konsumen dalam memilih pasar tradisional Ampel Boyolali sebagai tempat berbelanja. Hal ini berarti bahwa harga produk, kualitas produk, lokasi produk dan hari pasaran penting untuk dipertimbangkan dalam menjelaskan loyalitas konsumen dalam pasar tradisional sebagai tempat berbelanja. Apabila pedagang pasar tradisional dapat menentukan harga produk dengan tepat, kualitas produk yang tidak mengecewakan, lokasi pasar yang strategis dan hari pasaran maka dapat memikat dan meningkatkan loyalitas konsumen untuk berbelanja di pasar tradisional. Sedangkan itu untuk pelayanan pedagang yang tidak berpengaruh signifikan (negatif) terhadap loyalist konsumen dalam memilih pasar tradisional sebagai tempat berbelanja, bisa terjadi dikarena pelayanan pedagang kurang memuaskan membuat konsumen menjadi tidak loyal dalam memilih pasar tradisional sebagai tempat berbelanja. Secara simulatan harga produk, kualitas produk, lokasi pasar dan hari pasaran berpengaruh secara signifikan terhadap loyalis konsumen dalam memilih pasar tradisional sebagai tempat berbelanja.

\section{DAFTAR PUSTAKA}

Aji Setiawan, Mukhlas. 2007. Artikel. Pengamen, Pasar, dan Kota. Yayasan Pondok Rakyat. Yogyakarta.

Amstrong, Gary dan Philip, Kotler. 2002. Dasar-dasar Pemasaran. Jilid 1, Alih Bahasa Alexander Sindoro dan Benyamin Molan. Penerbit Prenhalindo. Jakarta.

Angipora, M. P. 2002. Dasar-Dasar Pemasaran. Raja Grafindo Persada. Jakarta.

Asri K. H. R. 2010. Analisis Perbandingan Sikap Konsumen dalam memilih Pasar Tradisional (Pasar Tugu Bandar Lampung) dan Pasar Modern (Candra Superstore Cabang Tanjung Karang). Universitas Lampung. Bandar Lampung.

Tjiptono, Fandy. 2000. Manajemen Jasa. Edisi Ketiga. Andi Offset. Yogyakarta

Mayasari R. 2009. Analisis Pengaruh Citra Pasar Tradisional Terhadap Loyalitas Konsumen. Skripsi. Universitas Sebelas Maret. Surakarta

Purnama, Nursya'bani. 2006. Manajemen Kualitas, Perspektif Global; Ekonisia; 2006; Yogyakarta.

Sutisna. 2003. Perilaku Konsumen dan Komunikasi Pemasaran. Cetakan 3. Remaja Rosdakarya. Bandung.

Sugiyono. 2012. Statistika untuk Penelitian. Alfabeta. Bandung. 